\title{
GRANULOMATOSIS WITH POLYANGIITIS: TREAT THE PATIENT NOT SYMPTOMS
}

\author{
Makharynska O. S. ${ }^{1}$, Lebedinska M. M. ${ }^{2}$,Skokova N. I. ${ }^{\text {, }}$ Oktiabrova I. I. ${ }^{1}$, Ajewole O. Michael, \\ Aroyewun O. Taofeeek ${ }^{I}$ \\ ${ }^{1}$ V. N. Karazin Kharkiv National University, Kharkiv, Ukraine \\ ${ }^{2}$ Kharkiv Medical Academy of Postgraduate Education, Kharkiv, Ukraine
}

Immunological mechanisms of appearance and therapeutic treatment strategies were discussed on example of the rare granulomatosis with polyangiitis clinical case in young patient. This vasculitis, formerly known as Wegener's granulomatosis, is a rare multisystem autoimmune disease with necrotizing granulomatous inflammation and pauci-immune vasculitis in small- and medium-sized blood vessels.

KEY WORDS: granulomatosis with polyangiitis, ANCA-associated vasculitis, prognosis, sinusitis

\section{ГРАНУЛЬОМАТОЗ ІЗ ПОЛІАНГІЇТОМ: ЛІКУЙТЕ ХВОРОГО, НЕ СИМПТОМИ}

Махаринська О. С. ${ }^{1}$, Лебединська М. М. ${ }^{2}$, Скокова Н. I. ${ }^{1}$, Октябрьова I. I. ${ }^{1}$, Аєволє О. Майкл ${ }^{1}$, Аройєвун О. Таофік

${ }^{1}$ Харківський національний університет імені В. Н. Каразіна, м. Харків, Україна

${ }^{2}$ Харківська медична академія післядипломної освіти, м. Харків, Україна

Імунологічні механізми виникнення і терапевтичні методи лікування було обговорено на прикладі клінічного випадку рідкісного гранулематоза з поліангіітом у молодого пацієнта. Цей васкуліт, раніше відомий як гранулематоз Вегенера, являє собою рідкісне багатосистемне автоімунне захворювання 3 некротизуючим гранулематозним запаленням і патчі-імунним васкулітом судин малого і середнього калібру.

КЛЮЧОВІ СЛОВА: гранулематоз із поліангіiтом, АNCA-ассоційованний васкуліт, прогнозування, синусит

\section{ГРАНУЛЕМАТОЗ С ПОЛИАНГИИТОМ: ЛЕЧИТЕ ПАЦИЕНТА, НЕ СИМПТОМЫ}

Махаринская Е. С. ${ }^{1}$, Лебединская М. Н. ${ }^{2}$, Скокова Н. И. ${ }^{1}$, Отябрева И. И. ${ }^{1}$, Аеволе О. Майкл ${ }^{1}$ Аройевун О. Таофик ${ }^{1}$

${ }^{1}$ Харьковский национальный университет имени В. Н. Каразина, г. Харьков, Украина

${ }^{2}$ Харьковская медицинская академия последипломного образования, г. Харьков, Украина

Иммунологические механизмы возникновения и терапевтические методы лечения обсудили на примере клинического случая редкого гранулематоза с полиангиитом у молодого пациента. Этот васкулит, ранее известный как гранулематоз Вегенера, представляет собой редкое многосистемное аутоиммунное заболевание с некротизирующим гранулематозным воспалением и паучи-иммунным васкулитом в сосудах малого и среднего калибра.

КЛЮЧЕВЫЕ СЛОВА: гранулематоз с полиангиитом, ANCA-ассоциированный васкулит, прогноз, синусит

\section{INTRODUCTION}

Granulomatosis with polyangiitis, formerly known as Wegener's granulomatosis, is Antineutrophil Cytoplasmic Autoantibody (ANCA)associated necrotizing vasculitis, with pathophysiological basis consisted from three components: necrotizing granulomatous inflamemation (most commonly in the upper or lower respiratory tract), granulomatous vasculitis of small and medium-sized vessels, including arteries, arterioles, capillaries and venules; and kidney disease (focal glomerulonephritis, often with necrosis and 
crescent formation). The group of ANCAassociated vasculitis is a group of diseases encompassing granulomatosis with polyangiitis (GPA), microscopic polyangiitis (MPA), and Churg-Strauss disease (eosinophilic GPA) [1]. The earliest complaints, in over $90 \%$ of patients with GPA, which are also the most common reasons for seeking medical attention, are usually related to upper respiratory tract problems including sinus pain, purulent nasal discharge, epistaxis, nasal ulceration, and serous otitis media. The presence of clinical signs such as supportive otitis, mastoiditis, a saddle-nose defect, and hearing loss should alert the physician for GPA [2]. Bilateral or unilateral pulmonary infiltrates are present in nearly $50 \%$ of patients initially, with lung disease eventually developing in $85-90 \%$ of patients [3]. Although renal involvement is clinically evident in only $11-20 \%$ of cases at presentation, glomerulonephritis eventually develops in $77-85 \%$ of patients, usually within the first two years of disease onset [4]. The diagnosis of GPA is difficult and often delayed due to the wide range of clinical presentations. Historically, the diagnosis of GPA has been made following the criteria of granulomatous involvement of upper and lowers respiratory tract, glomerulonephritis and varying degrees of systemic vasculitis. Fauci and colleagues [5] created effective definitive diagnostic criteria for GPA included clinical evidence of disease in at least two of three areas (upper airways, lung and kidney), and results that show disease in at least one and preferably two of these organ systems. Because biopsy based diagnosis required for GPA remains controversial, tissue diagnosis is recommended if a biopsy site is available, provided that the patient understands the risks of the procedure due to many of severe side-effects of specific for vasculitis therapy. CANCA directed against PR3 is most specific for GPA [6].

\section{CLINICAL CASE}

A 29-year old female was admitted 04-feb2017 by ambulance in the emergency department of 25 Kharkiv clinical multi-field hospitals with diagnosis: Bronchial asthma attack. She complains on body temperature $38^{\circ} \mathrm{C}$, ankles, hands, feet joints arthralgia, breathlessness, palpitation periodically, dyspnea and periodical cough with viscous sputum. She took at home aspirin and methylprednisolone.

\section{ANAMNESIS MORBI}

Patient was sick from august 2016, when during its trimester of pregnancy first time appeared high temperature $38^{\circ} \mathrm{C}$ and nasal stuffiness. Was treated by otolaryngologist with diagnosis allergic rhinitis. Medical miscarriage in 8th week. Gradually joined cough with periodical hemoptysis, pain in the throat, musopurulent nasal discharge. Due to appearance of body temperature $38^{\circ} \mathrm{C}$ again and pitting edemas with pain in ankles she was consulted in Poltava regional hospital by otolaryngologist, pulmonologist and rheumatologist with conclusion: Chronic bronchitis, chronic arthritis, reactive arthritis. Patient was treated with: antibacterial, anti-inflammatory and antiallergic drugs (exact drugs she couldn't name). Despite slight improvement she still noticed presence of periodical body temperature elevation and nasal discharge. Also in this period she noticed changes in her nose shape. In autumn 2016, she was treated 7 days in Poltava hospital with diagnosis Pneumonia.

From 22-nov-2016 until 29-nov-2016 patient was treated in Regional Kharkiv hospital with diagnosis Community-acquired bilateral pneumonia. Right sided partial spontaneous pneumothorax. Bilateral catarrhaledematous arthritis. Chronic bilateral perceptual-cum-neurological deafness. Reactive oligoarthritis (unknown genesis), with ankle joints affection. Hypotrophy syndrome. Chronic anemia. Thrombocytosis of unknown genesis. Mitral valve prolapse I degree with regurgitation I degree. Chronic heart failure 1 stage. Was treated there with: reosorbilact, enoxaparin, pantoprazole, and glucose $5 \%$, dexamethasone, $\mathrm{K}+$ chlorine solution, theophylline, fluconazole, meropenem, diclofenac and she felt better. For accurate diagnosis definition and exclusion of systemic connective tissue disorder, she was advised hospitalization to the rheumatology department but patient refused. Was recommended additional laboratory investigations as ANCA, anti-cardioliptin IgG, IgM; LE-cells, ANA, etc. From 05-dec2016 she noticed relapse of symptoms (cough with bloody-purulent sputum, dyspnea at rest, numbness of low extremities, purulent discharge from ear, $\mathrm{t}-38^{\circ} \mathrm{C}$, hair and weight loss) and 12-dec-2016 she was urgently admitted in the rheumatology department of Kharkiv regional hospital and then due to heaviness of her state she was transferred to 
ICU department. Chest X-ray: polysegmental pneumonia. Chest CT proved the character of pulmonary tissue changes: infiltration in S1-S2, S3-S6, and fibrosis after infiltration in S4. Several bronchoscopies were made with result: bilateral diffuse bronchitis III st., fibrinous inflammation, Streptococcus epid. 17.12.16 was made clinical sputum analysis and sputum culture: S. aureus $10^{2}$, sensitive to cefazolin, cefepime, ceftriaxone, amoxicillin, meropenem, amikacin, ofloxacin, clindamycin. 28.12.16 it was repeated: sputum culture - Candida, sensitive to clotrimazole, nystatin. In complete blood count (CBC) were found: anemia, leukocytosis with left shift, and thrombocytosis of unknown genesis. Urine analysis revealed: leukocyturia, proteinuria, hematuria, with 24 hours proteinuria $-0,98 \mathrm{~g} / \mathrm{l}$. Also patient had hyperglycemia with glycemic profile $6,0-12,3$ $-13,5-10,0 \mathrm{mmol} / \mathrm{l}$. Ultrasound conclusion from 14.12.16: sclerotic changes of aortic and mitral valves. Mitral regurgitation II degree. Pulmonary hypertension II degree $(32 \mathrm{~mm} \mathrm{Hg}$ ). Hepatomegaly and adipose changes of liver. Chronic cholecystitis. Chronic pyelonephritis. She was discharged after mild improvement with diagnosis: Community-acquired rightsided polysegmental pneumonia, 3 clinical group. Chronic bronchitis, exacerbation. LF I-II stage. CKD II stage: secondary nephropathy. Candydomycosis. Peripheral lymphadenopathy. Polyneuropathy of upper and low extremities, vegetal-sensual form. Reactive oligoarthritis (unknown genesis), with ankle joints affection. Hypotrophy syndrome. Metabolic cardiomyopathy. Mitral valve prolapse I degree with regurgitation II degree, pulmonary hypertension I stage. CHF 0 stage. Chronic anemia. Thrombocytosis of unknown genesis with hemorrhagic syndrome (upper and low respiratory tracts, kidneys involvement). Chronic atrophic rhino-pharyngitis. Acute leftsided purulent middle otitis, tympanum second membrane formation after acute otitis. Chronic subatrophic erosive laryngo-tracheitis. Acute bilateral catarrhal-edematous arthritis, reconvalescent. Firstly diagnosed diabetes mellitus. Hypocalcaemia. Systemic vasculitis? Blood disorder? She was treated enormous amount of drugs prescribed: gatifloxacin, vancomycin, doxycycline, piperacillin + tazobactam, cefepim, levofloxacin, fluconazole, nystatin, famotidine, omeprazole, etamzilat, vicasol, aspirin, vitakson, gabapentin, contrical, dexamethasone IV, methylprednisolone orally, biseptol (sulfamethoxazole, trimethoprim). During last hospitalization in Kharkiv region hospital in December 2016 several councils of physicians were made with differential diagnostics between antineutrophylic cytoplasmic antibodies (ANCA) associated vasculitis, Goodpasture syndrome and sepsis, but these diagnoses weren't confirmed despite ANCA positive analysis (1,05 U/l (N-till 1U/l)). She was recommended: methylprednisolone $12 \mathrm{mg}$ daily, moxifloxacin $400 \mathrm{mg}$ daily 10 days, biseptol (sulfamethoxazole+trimethoprim) $480 \mathrm{mg} 2$ times daily, nystatin $500 \mathrm{mg}$ daily 14 days, Ca supplements, consultation of hematologist and bone marrow trepan biopsy.

Preliminary diagnosis during hospitalization in 25 Kharkiv clinical multi-field city hospitals was Community-acquired pneumonia III clinical group, LF II stage. Anemia of unknown genesis.

\section{ANAMNESIS VITAE}

Childhood infections, injuries, tuberculosis, sexually transmitted diseases were denied by patient. Hereditary diseases are not identified. Allergic history is not burdened. Smoking denied, not an alcohol abuser. Family history: nothing clinically significant.

\section{OBJECTIVE EXAMINATION}

Conciseness - clear, state - severe, body position - active, $37,8^{\circ} \mathrm{C}, \mathrm{SpO} 2-94 \%$. Patient can orientate himself in place, time, and her personality. Saddle shape nose deformity. Pale skin and mucosae. Thyroid: not enlarged, soft. Peripheral lymphatic nodes - not enlarged. Smoothed contours of ankle joints, with moderate functional limitations in the ankles joins. Cyanosis of the skin in the area of proximal interphalangeal hands 2, 3, 4 joints. Breath rate $-26-30 / \mathrm{min}$. Chest is symmetrical, active respiratory muscles participation in breathing, retraction of intercostal spaces. Lung percussion: dull sound in lower parts. Lung auscultation: weak breathing, whizzing, and rales in lower lung lobes. Borders of the heart: without clinically significant changes. Heart auscultation: rhythmic, heart tones - muffled, systolic soft murmur over all points of auscultation. Heart rate (HR) - $140 \mathrm{bts} / \mathrm{min}$ Pulse - rhythmic, weak, $140 \mathrm{bts} / \mathrm{min}$. BP120/70 mm Hg. Abdomen: normal size, symmetric, unpainful. Liver: $+2 \mathrm{~cm}$, moderate density, no pain during palpation in right hypochondrium. Spleen: not palpated. 
Pasternatsky symptom - negative from both sides. Edemas: absent.

\section{LABORATORY AND INSTRUMENTALTESTS}

Complete blood count data presented in dynamic shows reactive or secondary thrombocytosis (RT), moderate hypochromic anemia specific for patients with systemic disorders, leukocytosis. Anti-neutrophil cytoplasmic antibodies have been known to be closely related to ANCA-associated vasculitis, including microscopic polyangiitis, granulomatosis with polyangiitis, eosinophilic granulomatosis with polyangiitis, and singleorgan ANCA-associated vasculitis, which often cause renal limited pauci-immune complex crescentic glomerulonephritis (CGN) and moderate thrombocytosis [7]. Coexistence of
ANCA and the immune complex may cause a far more active immune and inflammatory state, leading to an extremely high platelet count. There have been a considerable number of articles researching the association between thrombocytosis and cytokines such as IL-6, IL11 , and thyroperoxidase in inflammatory conditions such as infection and rheumatoid arthritis. A study on Chinese people indicated that RT is not rare in ANCA-associated vasculitis patients and it has an occurrence rate of about $20 \%$ [8]. Anemia is a common complication of patients with antineutrophil cytoplasmic antibody - associated renal vasculitis, as vessels in the kidney, skin, respiratory tract, gastrointestinal tract, and peripheral nerves are often involved [9].

Complete blood count data in dynamic

Table 1

\begin{tabular}{|c|c|c|c|c|c|c|c|c|}
\hline & $\mathbf{2 2 . 1 1 . 1 6}$ & $\mathbf{2 6 . 1 1 . 1 6}$ & $\mathbf{1 2 . 1 2 . 1 6}$ & $\mathbf{2 7 . 1 2 . 1 6}$ & $\mathbf{0 3 . 0 1 . 1 7}$ & $\mathbf{0 6 . 0 2 . 1 7}$ & $\mathbf{1 3 . 0 2 . 1 7}$ & $\begin{array}{c}\text { Normal } \\
\text { Range }\end{array}$ \\
\hline $\mathrm{Hb}, \mathrm{g} / \mathrm{l}$ & 87 & 77 & 94 & 85 & 65 & 70 & 75 & $130-160$ \\
\hline RBC, $10^{12}$ & 4,02 & 3,33 & 3,6 & 3,2 & 2,5 & 2,5 & 2,8 & $4.0-5.0$ \\
\hline Color index & 0,66 & 0,7 & 0,77 & 0,79 & 0,79 & 0,84 & 0,84 & $0,85-1,05$ \\
\hline WBC, $10^{9}$ & 10,5 & 8,7 & 12,1 & 20,3 & 11,1 & 9,9 & 6,7 & $4-9$ \\
\hline ESR, mm/h & 42 & 42 & 50 & 40 & 11 & 31 & 45 & $1-10$ \\
\hline Bands & 8 & 6 & 6 & 1 & 2 & 6 & 1 & $1.06-6 \%$ \\
\hline Segments & 82 & 74 & 79 & 73 & 70 & 72 & 58 & $47-72 \%$ \\
\hline Eosinophils & 0 & 5 & myelocytes & - & 1 & 1 & 2 & $0.5-5 \%$ \\
\hline Monocytes & 2 & 5 & 4 & 11 & 6 & 3 & 7 & $0.1-3 \%$ \\
\hline Lymphocytes & 8 & 10 & 10 & 15 & 21 & 18 & 32 & $19-37 \%$ \\
\hline Platelets & 781 & 472 & 1005 & 259 & 265 & 180 & - & $180-320$ \\
\hline
\end{tabular}

Although routine laboratory tests are generally nonspecific for ANCA-associated renal vasculitis, common laboratory findings in ANCA-associated renal vasculitis include leukocytosis, thrombocytosis, normochromic and normocytic anemia, and the elevation of acute-phase inflammatory proteins [9]. Anemia that occurs as a complication in these diseases is generally known as anemia of chronic disease (ACD, also called anemia of inflammation). The mechanisms of ACD are thought to be hepcidin-induced changes in iron metabolism, inadequate response of erythropoiesis, and shortening of the erythrocyte lifespan. Renal dysfunction is also an important cause of ACD.
Both renal anemia and ACD are mediated through the effects of inflammatory cytokines such as interleukin (IL)-1, IL-6, and tumor necrosis factor-alpha. Hepcidin, its increased levels seen in CKD patients, is the main regulator of iron metabolism, and its production is regulated by changes in the body's iron stores, inflammation, erythropoietic activity, and hypoxia [10].

Urinalysis of our patient showed proteinuria, leukocyturia, hematuria. 24 hours proteinuria was $0,98 \mathrm{~g} / \mathrm{l}$. Below represented urine analysis data in dynamic (see table 2.). ANCAassociated renal vasculitis is probably present in our patient according to changes in urine 
analysis. Kidney biopsy wasn't performed due to heaviness of the patient's health state, but histopathological findings in some studies demonstrated that renal interstitial damage present is associated with anemia severity.

Urine analysis data in dynamic

Table 2

\begin{tabular}{|c|c|c|c|c|c|c|}
\hline & 22.11.16 & 23.12.16 & 03.01.17 & 04.02.17 & 07.02.17 & $\mathbf{N}$ \\
\hline$\rho$ & 1.008 & 1,010 & 1,007 & 1,003 & 1,007 & $1.001-1.040$ \\
\hline glucose & - & - & - & - & - & abs \\
\hline protein & 0.2 & 1,8 & 1,9 & 0,054 & 0,216 & abs, $g / l$ \\
\hline WBC & $4-5$ & $25-30$ & $1 / 2$ of field & $10-15$ & $1 / 2$ of field & $1-2$ \\
\hline hyaline casts & - & $1-2$ & $3-4$ & $4-5$ & $2-3$ & abs \\
\hline granular casts & - & - & - & $5-6$ & $1-2$ & abs \\
\hline $\mathrm{pH}$ & 6,0 & 6,0 & 6,0 & 6,0 & 6,0 & $5-7$ \\
\hline $\mathrm{RBC}$ & $8-10$ & all field & $20-30$ & $35-40$ & $6-8$ & 0 \\
\hline other & ketone bodies & menses & fungi & - & salts & \\
\hline
\end{tabular}

In biochemistry analysis data significant were: periodical hyperglycemia (7.4$6,1 \mathrm{mmol} / \mathrm{l}$ ), elevation of creatinine levels $(124-138 \mathrm{mmol} / \mathrm{l})$, high level of potassium $(5,62 \mathrm{mmol} / \mathrm{l}$ within normal limits 3,5$5,1 \mathrm{mmol} / \mathrm{l})$, elevation of seromucoids concentrations - $721 \mathrm{U}(\mathrm{N}-135-200)$ and CRP - $60 \mathrm{mg} / \mathrm{l}$ (N 0-5). Hyperglycemia was a nearly universal occurrence in this severely ill population of medical patients. The severity and frequency of hyperglycemia during critical illness is determined in part by acute stimuli, including corticosteroids, exogenous catecholamine, and carbohydrates. Even among patients with normal baseline glucose control, higher (but still normal) glycated hemoglobin level was associated with more frequent and severe hyperglycemia. During critical illness, the usual correlation between $\mathrm{HbAlc}$ and plasma glucose is shifted, presumably through loss of homeostatic reserve [11]. Among immunological and serological investigations remarkable and clinically significant, diagnosis proven were: ANCA titer - 1,05 U/1 (N till 1,0), levels of rheumatoid factor $-120 \mathrm{mU} / \mathrm{l}(\mathrm{N}$ negat) which are specific for ANCA-associated vasculitis formerly known as Wegener's vasculitis. Rheumatoid factor is positive in a low titer in two thirds of patients, whereas antinuclear antibody is present in $10-20 \%$ of patients [6]. Also were made: anticardiolipin $\mathrm{IgM}-1,11 \mathrm{U} / 1(\mathrm{~N}$ till $7 \mathrm{U} / \mathrm{l})$, ANA - negat., LE-cells - negat., ACCP - negat., IgG to herpes - negat., IgG to CMV - negat., IgM to phospholipid and glycoprotein - negat, HIV negat., VCA IgM and VCA IgG - negat., PCR for herpes, cytomegalovirus (CMV), EpsteinBarr virus (VCA) - negat., Wassermann's reaction (RW) - 13.02.17 No. 9284-negat. Blood culture repeated several times 12.12; $21.12 ; 22.12 ; 23 / 12 / 16$ showed no grows, but in sputum was found sputum S. pneumonias $10^{8}$, sensitive to ceftriaxone. ECG during admission showed sinus rhythm, sinus tachycardia with HR -150 beats in min., metabolic disturbances.

In our patient chest $\mathrm{X}$-ray during admission in a direct and the right lateral projection was found on an inspiration and an exhalation is defined emphysema, diffuse pneumosclerosis. On the right, in the lower lobe, there is a focus of the lung tissue low transparency due to infiltration without clear contours. In the basal zones on both sides, there is an increase in pulmonary pattern according to the strend type. Sinuses are free. Ordinary diaphragm, normal excursion. Cardiovascular shadow within normal limits. Conclusion: Pneumosclerosis. Right-sided pneumonia.

Spirometry from 14.02.17. - VLC - 2,991 (84,3 \% from normal), FEV1, 1 - 1,67 (54\% from normal), FEV1/FVC - 99,7 $(0,9)$. Conclusion: stenosis of intrathoracic respiratory ways.

Otolaryngologist conclusion was: chronic rhino-pharyngitis, chronic left-sided cochleaneuritis. Neuropathologist: polyneuropathy of upper and low extremities, vegetal-sensual form. Pulmonologist considered that taking into consideration patient's clinical examination and laboratory investigations data, diagnosis of primary ANCA - associated systemic vasculitis (it is necessary to make differential diagnosis 
between Goodpasture's syndrome and Wegener's granulomatosis) could be the most reliable in this case.

After treatment in the therapy department was repeated chest $\mathrm{x}$-ray to check effectiveness of therapeutic strategy chosen. On the control chest X-ray positive dynamics seen. Infiltration is not present. There is some increase of the pulmonary pattern in the medial parts, because of the vascular component. Structural roots. Diaphragm is normal. Sinuses are free. Enlargement of heart shadow as the left border of the heart is widened. Conclusion: the residual changes after pneumonia.

\section{FINAL DIAGNOSIS}

Granulomatosis with polyangiitis with involvement of upper and lower respiratory ways, kidneys. Chronic rhino-pharyngitis. Chronic left-sided cochlea-neuritis. Polyneuropathy of upper and low extremities, vegetalsensual form. Metabolic cardiomyopathy. Mitral valve prolapse I degree with regurgitation II degree, pulmonary hypertension I stage. CHF 0 stage. Anemia of chronic disease, moderate.

\section{TREATMENT RECEIVED IN HOSPITAL}

Levofloxacin $500 \mathrm{mg} 1$ timelday, ceftriaxone $2 \mathrm{~g}$ IM 1 time/day, inhalations with moistened $\mathrm{O} 2$, dexamethasone $8 \mathrm{mg}$ IV 1 time daily, Hartmann's solution IV 200,0 $\mathrm{ml}$, ivabradin $5 \mathrm{mg} 2$ timelday, acetylcysteine $400 \mathrm{mg}$ a day, berodual (ipratropium bromide+fenoterol) inhalation 2 times/day; a combination of methylprednisolone in dosage $64 \mathrm{mg} /$ day and methotrexate in dosage $20 \mathrm{mg} /$ day as vasculitis-specific treatment.

\section{RECOMMENDATIONS}

Generally the prognosis of GPA has dramatically improved with the introduction of immunotherapy, there is still significant morbidity from the disease itself $(86 \%)$ or side effects from the therapy (42\%) [1]. The majority of patients, despite intensive treatment, experience relapses during treatment or even in remission. As disease's relapse is associated with poorer prognosis and increased mortality, effective treatment and prevention of further relapses in strictly recommended. Based on these therapeutic goals for our patient could be recommended:

1. The mainstay of treatment for granulomatosis with polyangiitis (GPA) is a combination of corticosteroids and cytotoxic agents. The choice of methotrexate with glucocorticoids combination as initial therapy was based on absence in our patient case nonorgan-threatening and non-life-threatening disease (no evidence for «active» glomerulonephritis or no organ-threatening or lifethreatening manifestations, patients may have rhinosinusitis, arthritis, and/or pulmonary nodules). For our patient was prescribed a combination of methylprednisolone in dosage $64 \mathrm{mg} / \mathrm{day}$ and methotrexate in dosage $20 \mathrm{mg} /$ day for 1 month with adjustment of therapy in future.

2. From November 2016 patient has hyperglycemia, so was recommended glycemic levels control in future with investigations for hyperglycemia genesis definition (C-peptide, $\mathrm{HbAc1}$ etc.).

3. Patients with GPA should have regularly scheduled follow-up visits with the physician primarily responsible for managing his or her disease. Since recurrences occur frequently, patients should be monitored closely clinically, with radiologic studies and laboratory examinations that include renal function, erythrocyte sedimentation rate (ESR), ANCA levels, and urinalysis.

4. Prophylaxis against Pneumocystis pneumonia is essential while patients are receiving conventional therapy for GPA. This can be achieved with trimethoprimsulfamethoxazole single-strength once daily or double-strength formulation three times per week. Dapsone $100 \mathrm{mg}$ daily can be used in sulfa-allergic patients. Also baseline bone mineral density should be evaluated because of high risk for glucocorticoid-induced osteoporosis. Routine laboratory tests are nonspecific in granulomatosis with polyangiitis. Rheumatoid factor is positive in a low titer in two thirds of patients, whereas antinuclear antibody is present in 10-20\% of patients. Whether tissue diagnosis is always required for GPA remains controversial. As the therapy for severe GPA is not benign, tissue diagnosis is recommended if a biopsy site is available, provided that the patient understands the risks of the procedure. C-ANCA directed against PR3 is most specific for GPA.

5. Causes of anemia in our patient with ANCA-associated renal vasculitis are multifactorial, and that while renal anemia is easily missed, it is the most frequent and influential cause of anemia in patients with 
ANCA-associated renal vasculitis. There is a possibility that the treatment for anemia itself would lead to an improvement in the prognosis of patients with ANCA-associated renal vasculitis [4]. In the future, therefore, it will be important to investigate the efficacy of earlier treatment initiation for anemia, the optimal timing of anemia intervention and the effectiveness of erythropoietin therapy.

\section{CONCLUSIONS}

Autoimmune diseases affect 5 to $7 \%$ of people, are commoner in women of childbearing age, and are frequently encountered in pregnancy. They may remit or improve during pregnancy, but can flare or present in pregnancy with disastrous consequences. Otorhinolaryngologist is the first physician to contact for the majority of patients with GPA. This diagnosis must always be taken into consideration in patients with recurrent upper respiratory tract infections, otitis, mucosal ulcers and laryngitis. Proper and early diagnosis is crucial for imminent therapy implementation and allows avoiding irreversible organ damage.

\section{REFERENCES}

1. Harper L. ANCA-associated renal vasculitis at the end of the twentieth century-a disease of older patients. / Harper L., Savage C. O. // Rheumatology (Oxford). - 2005. -No. 4. - p. 495-501.

2. Kubaisi B. Granulomatosis with polyangiitis (Wegener's disease): An updated review of ocular disease manifestations / B. Kubaisi, K. A. Samra, C. S. Foster // Intractable Rare Dis Res. - 2016. - No. 5(2). p. 61-69.

3. Cordier J. F. Pulmonary Wegener's granulomatosis. A clinical and imaging study of 77 cases. I J. F. Cordier, D. Valeyre, L. Guillevin, R. Loire, J. M. Brechot // Chest. -1990. - No. 97. - p. 906-912.

4. Hoffman G. S. Wegener granulomatosis: an analysis of 158 patients. / G. S. Hoffman, G. S. Kerr, R. Y. Leavitt, [et al.] // Ann Intern Med. - 1992. - No. 116(6). - p. 488-98.

5. Fauci A.S. Wegener's granulomatosis: prospective clinical and therapeutic experience with 85 patients for 21 years. / A. S. Fauci, B. F. Haynes, P. Katz, S. M. Wolff // Ann Intern Med. -1983. - No. 98(1). p. $76-85$.

6. Bossuyt X. Position paper: Revised 2017 international consensus on testing of ANCAs in granulomatosis with polyangiitis and microscopic polyangiitis. / X. Bossuyt, C. Tervaert, Y. Arimura, [et al.] // Nat Rev Rheumatol. - 2017. - No. 13(11). - p. 683-692.

7. Jennette J. C. 2012 revised International Chapel Hill Consensus Conference Nomenclature of Vasculitides. / J. C. Jennette, R. J. Falk, P. A. Bacon, [et al.] // Arthritis Rheum. - 2013. - No. 65(1). - p. 1-11.

8. Wang Y. The clinical and pathological characteristics of Chinese elderly patients with anti-neutrophil cytoplasmic autoantibodies associated small vessel vasculitis. / Y. Wang, M. H. Zhao, J. Yu, et al. // Exp Gerontol. - 2004. - No. 39(9). - p. 1401-5.

9. Tetsuya K. Anaemia is an essential complication of ANCA-associated renal vasculitis: a single center cohort study / K. Tetsuya, J. Usui, S. Kaneko, et al. // BMC Nephrol. - 2017. - No. 18. - p. 337-345.

10. Weiss G. Anemia of chronic disease. / G. Weiss, L. T. Goodnough // N Engl J Med. - 2005. No. 352(10). - p. 1011-1023.

11. Cely C. M. Relationship of Baseline Glucose Homeostasis to Hyperglycemia During Medical Critical Illness / C. M. Cely, P. Arora, A. A. Quartin [et al.] // Chest. - 2004. - No. 126(3). - 879-887. 